\title{
Long-term Career Impact and Professional Applicability of the Study Abroad Experience
}

\section{Kimberly Franklin}

\section{Introduction}

Research shows that study abroad experience affects professional qualifications. It is evident that employers value the skills and knowledge potentially gained from study abroad and that these competencies are transferable on the job. Johnson and Kaufman note that specific focus is given to intercultural competencies gained from an international experience and that this could be essential to career success in the global marketplace (Johnson and Kaufman 2005). Others point to various marketable and real world skills that are carried by study abroad college graduates (Asia Society and The Goldman Sachs Foundation 2005). In a RAND Corporation study, employers for globalized jobs cite cross-cultural competencies and interpersonal skills used in problem-solving as prime criteria used when evaluating job candidates (Matherly and Nolting 2007). In another study, CEO perspectives were obtained to help develop and define an employee profile for high potential in the workplace. Findings indicate that "studying abroad and internationally oriented studies are mentioned as essential and basic requirements for enhancing talent" and that there is a need for "people who can work from a variety of perspectives" (Hermans 2007, 513-514). Results from another employers survey found that European mobile (study abroad) alumni have stronger professionally relevant competences then non-mobile students (Teichler and Janson 2007, 486-495).

Study abroad outcomes assessments are routinely conducted immediately following a participant's return from abroad, or shortly after graduation. The majority of research focuses on the impact of study abroad in the areas of language acquisition, knowledge gained, and changes in personal values, attitudes, and interests. The Georgetown Consortium Project is a comprehensive example of such. The central question that drove the research was, "What is it that our students are learning while abroad?" With a wide-ranging scope of focus, student learning was evaluated in three areas: gains in second-language oral proficiency, gains in intercultural sensitivity, and learning within a disciplinary context (Balkcum, Scheid, Vande Berg, and Whalen 2004). Further studies exploring the immediate impact of study abroad and provide evidence of study abroad out- 
comes from work abroad programs (Hannigan 2001), business school (Kruze, Orahood, and Pearson 2004), community colleges (Brennan, Frost, Hagadorn, Martin and Natali 2005), and service learning programs (Wanasek 2005). Nearly all known research lacks a longitudinal component.

Of the few studies that focus on long-term outcomes, only three address professional development. Each asks two quintessential questions: 1) Do alumni gravitate toward working in an international capacity, and 2) Was career direction influenced by their experience. The Institute for the International Education of Students (IES) longitudinal study examining the long-term impact of study abroad on 50 years worth of study abroad alumni stands out as groundbreaking in the field. This comprehensive study's primary purpose was to determine how the experience impacted the participants' lives years later. Findings indicate that respondents' study abroad experiences had a large impact on their personal lives, and a lesser effect on their careers, and political and social views (Dwyer and Norris 2005). The portion of the study that covered professional development demonstrated a significant impact on career path. 48 percent of survey respondents worked or volunteered in an international capacity at some point since college, 62 percent of participants had their career direction ignited by their study abroad experience, and 77 percent acquired skills abroad that influenced their career path (Norris and Norris 2005). Characteristics such as program duration, program type, and internship participation varied outcomes (Dwyer 2004).

The SAGE Research Project at the University of Minnesota abroad is currently conducting an alumni study on the long-term impact of study abroad. This research project is a retrospective tracer study of over 6,000 former study abroad participants from 22 different U.S. American colleges, universities and education abroad providers covering 50 years of alumni. Their preliminary results indicate that 24 percent of alumni have an international dimension to their career, and that in choosing a career 32 percent were influenced by their study abroad experience (Fry and Paige 2008).

Additional research on the long-term impact of study abroad was reported by Ostanina. Her study focused on Central College alumni personal growth, outlook on life and the world, behavioral changes on career and education, and motivation to maintain interest in international matters as a result of studying abroad. She reports that 63 percent of alumni have an international/intercultural dimension in their jobs and 49 percent considered their experience to have affected their career choice (Ostanina 2005). 


\section{Study Design}

This study aimed to evaluate if and how study abroad has long-term impact on participants' professional development. It investigates the professional outcomes and benefits of studying abroad as perceived by study abroad alumni ten years following their undergraduate experience. Participants were questioned about the skills, knowledge, and self-awareness they acquired and maintained from their study abroad experience. Inquiries were made into how and if these acquisitions proved professionally applicable, influenced career paths, included work with international dimension, and contributed to success.

Participants in the study are Dickinson College alumni from the class of 1998 who studied abroad on at least one occasion during their years as an undergraduate. The subjects were identified with the cooperation of the Dickinson College Offices of the Registrar, Institutional Research, and Global Education. A complete list of 189 study abroad alumni was compiled from a class of 435 graduates. At the time the data was collected, these individuals had just passed the 10-year anniversary of their graduation. This marked an interesting point for a longitudinal case study of professional outcomes because an adequate amount of time had passed for alumni to settle into a career such that useful data could be attained.

To achieve a valid research design, a mixture of qualitative and quantitative methodologies was used to collect data. This was accomplished through the use of a survey, phone interviews, and a group that received follow-up questions by email in an effort to triangulate data. The primary instrument used in collecting both quantitative and qualitative data was an online survey. Using a survey allowed for asking both scaled and open-ended questions. It enabled comparison to be made between professional outcomes and study abroad variables. The use of a survey instrument is widely used in international education. Measuring data in a manner similar to other study abroad alumni research projects makes it manageable to compare and contrast findings. Like that of other study abroad outcome assessment surveys, the majority of the survey questions followed a format close to the Intercultural Development Inventory (IDI) using a response set ranging from strongly agree to strongly disagree. One question closely follows the format of the Strategies Inventory for Learning Culture (SILC) using a response set ranging from frequently to never, including an option of not applicable (Paige and Stallman 2007, 144). Both the IDI and SILC are self-assessment tools and appropriate for alumni retrospective responses.

In developing the survey, comparable alumni studies were considered and questions were modified and added based on the nature of this research and its target respondents. Administrators from the Dickinson College Office of 
Global Education and the Office of College Relations were involved in providing insight, guidance, and testing of the survey, which included questions about general demographic information, study abroad program details, and a description of professional experience. Once finalized alumni were contacted directly by Dickinson College's Associate Vice President of College Relations by email, invited to participate in the study, and provided with a link to the online survey.

A total of 52 alumni completed and returned the survey. If survey participants responded that they were willing to be contacted again, a second intervention was made to collect supplementary qualitative data. Each of these respondents was emailed requesting participation in one of two additional measures of data collection. Among this group of individuals nine were randomly selected to participate in the first of these two measures, a phone interview. Six individuals ultimately participated in the phone interview, reflecting roughly 12 percent of the respondent population. Following email correspondence, each of these subjects was called at a time, date, and phone number of their request. The phone interview lasted roughly a half an hour and consisted of open-ended questions about their current work, job applications, previous work, goals, advanced degrees, reflective advice to others based on their experiences, and the city and state in which they work. These points of inquiry evolved out of questions raised following review of the survey data.

Of the remaining 29 survey participants that were willing to be contacted a second time, 15 responded to an email requesting further information. This group was asked for the city and state in which they worked, to clarify their answers given in the survey (i.e. incomplete fields, conflicting data, explanations when 'other' was chosen as an answer, etc), and to elaborate on the statement they gave in the survey on the aspect of study abroad that they find most valuable as they pursue their career.

Using the data collected in the survey, raw numbers to responses were tallied and statistical percentages were produced. From the qualitative data collected in the survey, phone interviews, and emails, themes were distinguished and patterns appeared after sorting respondents by demographic and study abroad program characteristics. This enabled comparisons to be made between subjects and the impact study abroad had on their professional life. Conclusions were drawn and verified based on the cross-comparison of data.

The design of this study also had its limitations. Its weakness is in the lack of a control group. Subjects were limited to study abroad participants, and did not include alumni from the same graduating class who were exclusively campus-based, having no study abroad experience. Therefore the results of the study can correlate, 
but not suppose causation. Surveying both groups of alumni may lead to more conclusive results about the impact of study abroad on professional outcomes.

Further, this study is limited in that data comes from self-reflection about professional outcomes. Without questioning the employers of these subjects, one cannot conclude with certainty that study abroad experience contributes to the reason for hire or success within an organization. This could be a topic for extended research.

\section{Presentation and Analysis of Data Demographic Profile}

The gender distribution among survey respondents revealed a higher number of women ( 69.2 percent) then men ( 30.8 percent). This was expected since more women ( 74 percent) compared to men ( 26 percent) studied abroad in the graduating class. These figures are relatively consistent with the female/ male ratio reported in the Institute of International Education's (IIE) Open Doors Report on International Exchange for the year of 1996-97, the year in which the vast majority of these Dickinson alumni studied abroad. IIE reports that in that year, 64.9 percent of U.S. American students studying abroad were female and 35.1 percent were male (Institute of International Education 2007, November). Among survey participants, 37 percent reported graduating with multiple majors. Of those, 50 percent majored in an international/regional area and 33 percent majored in a foreign language. Overall, 32 percent majored in an international/regional area and 23 percent were foreign language majors. The most popular major was International Studies capturing 15.4 percent of all survey respondents. Political Science and English followed this closely in a tie at 13.5 percent. The remaining reported majors included Spanish at 11.5 percent, Economics and History both at 9.6 percent, French and Policy Studies both at 7.7 percent, Biology and East Asian Studies both at 5.8 percent, German, Italian Studies, Latin American Studies, Music, Psychology, and Russian Studies all at 3.8 percent, and Anthropology, Environmental Science, Fine Arts, Geology, Philosophy, and Religion all at 1.9 percent.

Data on the highest degree attained by survey respondents indicates that slightly over half ( 54 percent) of respondents attained a degree beyond their B.A. This is in direct proportion with what Dickinson's Career Center reported on the average number of graduates with advanced degrees. They state that, "according to data from the student clearing house, 54 percent of Dickinson graduates have advanced degrees" (P. Mullane, personal communication, May 13, 2008). This suggests that study abroad participation has no bearing on additional degree 
attainment. Of respondents who attained a degree beyond their undergraduate work, the majority (82.1 percent) earned a Masters (MA, MS or MBA), 10.7 percent earned a Juris Doctorate (JD), 3.6 percent earned a Philosophy Doctorate $(\mathrm{PhD})$, and 3.6 percent earned a Medical Doctorate (MD).

\section{Field of Work by Sector}

An overwhelmingly high percentage of alumni work in the field of education (21.2 percent). This is two-thirds higher than that of the next most popular field, which is banking/finance at 13.5 percent. The third most common professional field of work fell under "other" (11.5 percent) and include research, consulting, and archives. The remaining fields of work listed in order of popularity include Marketing/Sales and Health/Medical at 7.7 percent each, Business/Entrepreneur, Computer/Technical, Government/Military, and Law all at 5.8 percent, Non-profit, Science, and Travel/Tourism all at 3.8 percent, and Arts/Entertainment and Engineering/Architecture at 1.9 percent each.

\section{Study Abroad Experience \\ Participation by Region}

Nine of the 52 survey participants (17.3 percent) reported that they had two or more study abroad experiences during their undergraduate years at Dickinson College. Alumni reported a total of 63 study abroad experiences. Of those experiences, 79.4 percent were in Europe, 7.9 percent in Asia, 5.8 percent in Latin America, 3.2 percent in Africa, 3.2 percent in Oceania (Australia only), and 1.9 percent in North America. The top three destinations in order of popularity were England, Spain, and Italy. This is not consistent with what the Institute of International Education's (IIE) Open Doors Report indicates for the regional distribution of U.S. students studying abroad in 1996-97, the year in which the majority of survey participants studied abroad. IIE reported that in that year 64.5 percent of students' host region was in Europe, 6.1 percent in Asia, 15.3 percent in Latin America, 15.3 percent in North America, 2.6 percent in Africa, 4.4 percent in Oceania, and 1.9 percent in the Middle East (Institute of International Education 2007, November). The numbers most differ in the regions of Europe and Latin America. While cause for the sizeable difference is unknown, one can speculate that it is because numerous Dickinson-hosted programs are based in Europe and none at the time were hosted in Latin America. According to the Dickinson College Office of Global Education website, these programs are "developed and directly managed by the College and led by an on-site director who may be a Dickinson professor or a representative from the host institution. 
They have been created by academic departments at Dickinson as extensions of the department's curriculum and are monitored by them. Approximately 70 percent of Dickinson students who study abroad participate in a Dickinson Program" (Dickinson College Office of Global Education 2008). Therefore if the vast majority alumni from the class of 1998 participated in Dickinson programs, it makes sense that the regional numbers will reflect their location.

\section{Participation by Program Duration}

Taking into account that nine survey respondents participated in more than one study abroad program, results indicate that 59.6 percent of participantsstudied abroad for a minimum of one academic year. This includes five individuals who participated in two semester-long programs totaling a full academic year. The data presents a distribution of participants by minimum duration abroad as follows: Academic Year (59.6 percent), Semester (25 percent), and Short-term (15.4 percent). For the purposes of this study, short-term is defined as a four to seven week period, which includes summer and January-term programs.

The majority of participants studied abroad for a full academic year. This is consistent with the Open Doors report of Dickinson's high rank of $5^{\text {th }}$ among baccalaureate institutions for long-term study abroad duration.

\section{Language Use in an Academic Setting}

Survey participants responded to the question of "What language were your classes taught in" by choosing one of three answers: English, a non-English language of host country, or a combination of English and a non-English language of the host country. Based on the total number of student experiences, results show that a 41.3 percent majority was taught exclusively in a non-English language. 34.9 percent were taught in English and 23.8 percent were taught using a combination of English and a non-English language of the host country.

\section{Program Classification}

In an attempt to categorize academic programs, alumni were asked to respond to the question, "What type of study abroad program did you participate in?" The answer choices are listed below and correspond with definitions used.

- Integrated University Study (direct enrolment in an overseas university)

- Classroom Study Abroad Program (courses designed for non-native students) 
- Field Study Program (field study and research as the central component)

- Hybrid or Mixed Program (a combination of the preceding types)

The majority of all student experiences (42.9 percent) were Classroom Study Abroad Programs, followed by Integrated University Study (27 percent), Hybrid or Mixed Program (20.6 percent), and Field Study Program (9.5 percent).

\section{Student Housing}

Alumni were also asked the question "What was your primary type of student accommodation?" Based on the total number of student experiences, the resulting distribution of housing arrangements are as follows:

- Homestay, living in a home with a Local Family (36.5 percent)

- Living in a dormitory or apartment with a fellow Program Participant (38.1 percent)

- Living in a dormitory or apartment with a Local Student (11.1 percent)

- Other (14.3 percent) (Note: A dormitory single is the predominant housing arrangement under the category of "other." This information was gathered through a second intervention with survey participants to clarify data.

\section{Internship Participation}

Of the survey sample, 25 percent of survey respondents participated in an internship during their study abroad experience. This is not proportionate with the 51 percent of IES study abroad alumni found to have participated in an internship during the 1990's (Dwyer 2004, 158).

\section{Professional Impact}

Areas of long-term career impact from study abroad include gravitation toward international or multicultural jobs, choice of profession, economic returns, and the value of alumni by employers (Evans and Meyer-Lee 2007, 6667). Empirical data from survey, interview, and email inquiry group responses speak to these outcomes as well as others in the area of professional achievement and the effects of personal learning.

\section{Gravitation Toward International or Multicultural Jobs}

The number of alumni whose professional work involves an international or multicultural dimension is significant. When responses strongly agree and 
agree are combined, the data indicates that 73 percent of alumni have professions involving an international or multicultural dimension. Although it is impossible to decipher how many of respondents work in an international capacity as opposed to a multicultural capacity, the combined figure is nevertheless high. As mentioned in the literature review, preliminary results from the Sage Research Project indicate that 24 percent of alumni have an international dimension to their career (Fry and Paige 2008), notably less than Dickinson alumni participating in this study. It can be inferred that at least 58 percent of Dickinson alumni respondents work in an international capacity rather than solely a multicultural capacity because 58 percent strongly agree or agree that their work involves communication with international contacts. Supporting this, a notably high percentage of survey participants ( 46.2 percent) also responded yes when asked, "Have you ever worked for a multinational corporation or organization?"

Alumni comments on how their work involves an international or multicultural dimension include:

"It [study abroad experience] helps me...relate to international clients in my current job.”

"I could not be in my current position interacting with the Head of the UNDP-Kemal Dervis_or the former Secretary General of the UNKofi Annan-or countless other international figures without having had my eyes opened by study-abroad in Yaounde."

"I deal with international clients from time to time and drawing from that experience and talking to them about it has helped with relating to them personally."

"I practice international labor law, representing migrant workers. I work 40 percent of the time in Spanish and represent a client base that is overwhelmingly Latin American."

"I often work with European and English clients. My experience in their country leads to the development of strong personal relationships, often resulting in winning the business, client referrals, etc."

"My current research is based around German educational exchange programs." 
Significantly, results indicate that alumni whose professional work has an international or multicultural dimension are most likely to have lived in a homestay during their study abroad experience. Alumni who do not have an international or multicultural dimension to their careers are most likely to have lived with fellow U.S. program participant. Alumni whose professional work has international or multicultural dimension are also more likely to have taken their coursework in a non-English language. Their peers without this dimension to their careers are more likely to have been taught classes in English. These two findings confirm IES findings that it is a common occurrence among alumni who have an international dimension to their careers to have lived in a homestay or with a local student roommate, and participate in a non-English language program (Norris and Norris 2005).

Insignificant correlations were made between alumni who have careers with an international or multicultural dimension and program type, duration, and internship participation. Each of these three areas is statistically similar in proportion to alumni without an international or multicultural dimension to their career. In comparing these two alumni professional outcome groups, the most popular field of work is the same (Education) and they are roughly equal in their likelihood to earn a graduate degree.

In the interest of probing more into the international dimension of alumni careers, survey participants were asked, "Have you ever traveled abroad for work?." 34.6 percent responded yes, and 65.4 percent responded no. The primary reasons for travel were: conducting research, speaking engagements, launching a project or program, conferences, training, raising money, meetings, sourcing, and business due diligence.

When survey participants were asked, "Have you ever lived abroad for work," 13.5 percent responded yes and 86.5 percent responded no. Those who responded yes worked in tourism positions, public relations, business, and the predominant position, teaching English.

\section{Career Choice}

Forty-two percent of survey participants strongly agreed or agreed that their study abroad experience influenced their choice in career. This is a significantly lower proportion of alumni than what was found in the IES alumni study. IES results indicate that 62 percent of alumni had their interest in career direction ignited by their study abroad experience (Norris and Norris 2005). It is insignificantly lower than results reported by Ostanina in her study of Central College study abroad alumni. Her research indicates that 49 percent of alumni thought their study abroad sojourn 
affected their career choice (Ostanina 2005). It remains unknown why the results of these outcome studies differ in the area of career choice. One possibility for the variance may be in the interpretation of text. Each study uses slightly different wording to ask essentially the same question.

Several enthusiastic statements from Dickinson alumni support the idea that study abroad experiences influence professional choices. Examples of such can be found in the following participants quotes:

"My study abroad experience helped form the foundation of who I am today-personally and professionally...[I] chose to work in eco-tourism at non-profits as a result of my international travel exposure. I'm passionate about my career and love to use my language and knowledge of different cultures on a regular basis in my work."

"It was [when studying abroad] in Italy that I discovered my interest in international relations. I then decided that I wanted to go to grad school and did so, in London, getting a masters in international relations."

"It was studying abroad that made me choose my career [in international education]. I liked the programs and their processes so much that I wanted to help those wishing to study in America."

"My passion for literature and culture was sparked by the Dickinson program abroad in Malaga, Spain and I continue to love being fully immersed in the culture and all that it brings to enrich ones life. I currently work in Private Equity, which is an American concept of equity investments [in Spain]."

Following the survey inquiry on study abroad influence on career choice, the question of career satisfaction was addressed. Of all respondents, 39 percent strongly agreed to career satisfaction, 54 percent agreed, 8 percent disagreed, and 0 percent strongly disagreed. More importantly, the data tells us that alumni who were strongly influenced by study abroad in career choice have the highest level of career satisfaction. 90 percent of those who strongly agreed to being influenced, strongly agreed to career satisfaction. 33 percent of those who agreed to being influenced strongly agreed to career satisfaction. 29 percent of those who disagreed to being influenced strongly agreed to career satisfaction. 


\section{Economic Returns}

Data gathered from this study was unable to answer whether or not students' investment in study abroad has individual long-term economic benefit. In terms of salary measurements, survey findings indicate that the Dickinson study abroad alumni average annual income is higher than the national average (See Table 1). This is true for both men and women in the case of individuals with a BA/BS only and in the case of those with an advanced degree. National figures were taken from the U.S. Department of Labor's Bureau of Labor Statistics report in the third quarter of 2007 for full-time wage and salary workers age 25 and over (U.S. Department of Labor 2008).

Table 1 National vs. Dickinson College Alumni Sample Average Annual Incomes

\begin{tabular}{|l|l|l|}
\hline & $\begin{array}{l}\text { National Median } \\
\text { Weekly Earnings x 52 }\end{array}$ & $\begin{array}{l}\text { Dickinson Study } \\
\text { Abroad Alumni } \\
\text { Average Annual Income }\end{array}$ \\
\hline BA/BS Degree Only & & \\
\hline Women & $\$ 45,136$ & $\$ 71,114$ \\
\hline Men & $\$ 59,332$ & $\$ 122,333$ \\
\hline & & \\
\hline Advanced Degree & & \\
\hline Women & $\$ 56,160$ & $\$ 59,431$ \\
\hline Men & $\$ 76,7000$ & $\$ 106,444$ \\
\hline
\end{tabular}

Taking into consideration that only 1.1 percent of the U.S. student population studies abroad (Jongsma 2007), it can be inferred that less than 98 percent of the individuals included in the national figures in Table 1 have studied abroad. While survey participants who have studied abroad make more money than the national average, it cannot be concluded that the cause of higher earnings is based on this experience. If data on the annual incomes of campus-based Dickinson alumni from the class of 1998 were collected, it would be interesting to compare the groups side by side and draw conclusions within the sample.

In thinking about the economic return of study abroad, consideration should also be given to institutional giving. For the Dickinson College class of 1998, the institutional giving participation rate is significantly higher for alumni who studied abroad than for that of their campus-based peers. Consistently for the fiscal years of 2005, 2006 and 2007, study abroad alumni gave at a rate of 34.9 percent, 33.9 percent and 29.1 percent respectively. In those same years, alumni who did not study abroad gave at a rate of 23.9 percent, 19.1 percent and 16.7 percent (See Table 2) (K. Marcello, personal communication, July 10, 2008). This suggests that study abroad alumni may be more loyal to their alma mater. This could be due to positive experiences associated with studying abroad. How- 
ever, the average dollar amount gifted to the College is significantly and consistently lower than that of alumni who did not study abroad. For the fiscal years of 2005, 2006 and 2007, alumni from the class of 1998 who did not study abroad gave average amounts of $\$ 233, \$ 129$ and $\$ 565$ respectively. In those same years, alumni who studied abroad gave averages of $\$ 68, \$ 75$ and $\$ 90$. This suggests that alumni who did not study abroad have more economic resources, possibly earning a higher income and choosing different types of careers than alumni who studied abroad. Further research in this area is needed to draw conclusions.

\section{Value as Employees}

Although this research does not present an employer point of view, alumni are able to speak to their professional value by reflecting on their experiences. 73 percent of alumni respondents strongly agree or agree that their study abroad experience makes them more competitive in the job market. Representative comments include:

“1) Language fluency; 2) Cross-cultural communication. These two things allow me to be effective in my work with people from all over the world. My language skills make me more readily employable, and my cross-cultural communication makes me more effective once hired."

"I also think diversity on a resume counts for something. I help out with interviewing new candidates from time to time and seeing study abroad experience on a resume always impresses me. It suggests to me that the candidate is adventurous and probably independent and has most likely worked or studied in a diverse environment."

"I think that having the experience of living in an different country...makes a candidate for a job much more attractive due to adaptability and capacity to learn and succeed in many different environments."

The RAND Corporation study suggests that employers value inter-cultural competencies and interpersonal skills when evaluating job candidates (Matherly and Nolting 2007). In consideration of this, one could reason that Dickinson study abroad alumni are well-qualified job candidates that have potential to be hired in the globalized job market. The vast majority ( 72 percent) of survey respondents strongly agreed or agreed that their study abroad experience has helped them to understand situations at work in a cultural context. The vast 
majority (69 percent) also strongly agreed or agreed that their study abroad experience has increased their ability to problem-solve in a cultural context. Comments from alumni affirm this sentiment:

"The exposure to a different culture, actually many different cultures...helped me to see there are many different ways to approach an issue, challenge, etc."

"My experience overseas has helped me to better understand the cultural context of the Spanish language, which has made me a better and more effective teacher."

"We are currently doing a research study on coastal tourism development in Costa Rica working with a team of researchers in-country. Everyone there speaks English, but knowledge of Spanish and being able to relate to colleagues on other levels is helpful in developing a positive team repoire."

"Living in a foreign country taught me to step back and try to understand a situation and where [a] person is coming from."

\section{Areas of Achievement: Success, Professional Development, and Ethics}

It is evident from the data collected that study abroad has a strong impact on professional achievements. 64 percent of survey respondents indicated that they strongly agree or agree that their study abroad experience played a role in their professional success. 69 percent of survey respondents indicated that they strongly agree or agree that their study abroad experience plays a role as they continue to develop professionally.

The majority (60 percent) of respondents also strongly agreed or agreed that their study abroad experience influenced their sense of professional ethics. One respondent in a phone interview commented on how his study abroad internship experience influenced his professional ethics by learning about the professional ethics of others. Regarding that outcome he commented, "When you work with people from other cultures, you really begin to understand the ethics that drive their disposition." He also advised, "study abroad participants would do well to do an internship abroad...to expand their experience base." This in part confirms faculty reports from the Georgetown Consortium Project. Their findings indicate that from study abroad "students develop or enhance....an understanding of ethical and professional responsibility...” (Balkcum, Scheid, Vande Berg, and Whalen 2004). 


\section{Personal Learning as Professionally Applicable}

Meyer-Lee and Evans write that students' personal learning "can be broadly categorized into four categories of development: language skills, intercultural competence, disciplinary knowledge, and social growth" (Meyer-Lee and Evans 2007, 63). Findings of this study demonstrate that these areas of personal learning have a strong influence on professional outcomes.

\section{Language Skills}

Of those alumni who reported using a non-English language during their study abroad experience, 74 percent continue to use it in a professional capacity. 29 percent use it frequently, 14 percent use it sometimes, 31 percent use it rarely, and 26 percent never use it.

There is a correlation between student housing arrangements while studying abroad and the long-term use of a foreign language in a professional capacity. Alumni who lived in a homestay or with a local student are much more likely to use foreign language in their careers. Of alumni who responded that they use a non-English language in a professional capacity frequently or sometimes, 80 percent lived in a homestay or with a local student

\section{Intercultural Competence}

Survey data overwhelmingly supports the notion that alumni professionally apply their intercultural competencies gained from studying abroad. These competencies can be subdivided into three areas: cognitive/knowledge, affective/ attitudes, and behavior/skills (Meyer-Lee and Evans 2007, 64-65). Key terms used by alumni fit into these divided areas and are presented below.

\section{Cognitive/Knowledge}

A very popular theme taken from alumni responses was an increase in cultural understanding and knowledge. 69.2 percent of alumni strongly agreed or agreed that knowledge gains from the study abroad experience can be applied in their professional work.

\section{Affective/Attitudes}

When alumni were asked to comment on the aspect of their study abroad experience that they find the most valuable as they pursue their career, the most popular response was a gain or change in perspective. Alumni wrote: 
"It has broadened my train of thought and helped to consider multiple perspectives with regard to my professional work."

“...my eyes opened by study-abroad in Yaounde. Anyone considering a life in the political, non-profit, or development world should participate in a program like that of Dickinson's Yaounde experience."

"I think I have gained a perspective from being abroad that makes me a better teacher..."

"I realized how similar yet very different a culture can be from the U.S. It showed me that the world is a host of varying shades...not just black and white."

Another very popular response was awareness of self. In fact, an overwhelming 88.5 percent of alumni strongly agreed or agreed that self-awareness gains from their study abroad experience can be applied in their professional work. Only 6 individuals out of 52 alumni respondents ( 12 percent) disagreed with the statement that self-awareness gains are applied professionally.

\section{Behavior/Skills}

67.3 percent of alumni strongly agreed or agreed that skills gained from their study abroad experience can be applied in their professional work. The most popular theme found throughout open-ended responses in the survey was in reference to the skill of being able to cross-culturally communicate and relate to others as a result of their study abroad experience. Alumni comment that:

"I believe that when studying abroad you acquire communication, social, and other soft-skills that are applied more broadly in all aspects of your life."

"My study abroad experience has enhanced my communication skills, allowed me to become more open-minded and have a greater understanding of people in relation to their environment, culture, and country."

"Understanding of diverse cultures and backgrounds helps me to relate to people of other ethnicities."

"I taught me how to get along with people of all cultures." 


\section{Social and Emotional Growth}

Another popular response from alumni points to personal growth from study abroad in the areas of confidence, independence, maturity, and foundation-building as professionally applicable. The following statements from alumni are responses to the question that asks about the most valuable aspect of their study abroad experience as they pursue their career:

"I would say that studying abroad helped me grow confidence and independent thinking as well as engaging in unfamiliar situations with new people and that personal growth is most valuable to my career regardless of the type of work I do."

"Probably confidence to know that no matter how unfamiliar at topic, with determination and persistence I will master it successfully."

"My study abroad experience helped form the foundation of who I am today-personally and professionally."

"My experience being away from the Dickinson bubble and being forced to become more independent, interact with people from all over the world, and experience a totally different school and city environment helped shape me."

"I am much more well-rounded and confident...that started during my year abroad."

"I grew up and learned to be an adult and cherish those memories and lessons."

"I certainly matured while living in Europe."

\section{Statistical Summary of Data}

In almost every area questioned, the majority of alumni agreed that their study abroad experience impacted their lives with favorable professional outcomes (see Table 2), and only two of 52 respondents disagreed with all statements.

\section{Conclusions}

This outcomes-based study explored the logic that study abroad has long-term impact on participants' careers. It questioned how does study abroad impact participants' career path and professional development. The results strongly suggest that 
Table 2 Summary of Professional Outcomes Influenced by Study Abroad

\begin{tabular}{|l|l|l|}
\hline My professional work involves... & Agree* $^{*}$ & Disagree $^{*}$ \\
\hline An international or multicultural dimension & $73 \%$ & $27 \%$ \\
\hline Communication with international contacts & $58 \%$ & $42 \%$ \\
\hline & & \\
\hline My study abroad experience... & $71 \%$ & $29 \%$ \\
\hline $\begin{array}{l}\text { Has helped me to understand situations at work in a } \\
\text { cultural context }\end{array}$ & $69 \%$ & $31 \%$ \\
\hline $\begin{array}{l}\text { Has increased my ability to problem-solve at work in a } \\
\text { cultural context }\end{array}$ & $42 \%$ & $58 \%$ \\
\hline Influenced my career choice & $73 \%$ & $27 \%$ \\
\hline Has made me more competitive in the job market & $63 \%$ & $37 \%$ \\
\hline Has played a role in my professional success & $69 \%$ & $31 \%$ \\
\hline Makes a difference as I continue to develop professionally & $60 \%$ & $40 \%$ \\
\hline Contributed to my sense of professional ethics & & \\
\hline & $69 \%$ & $31 \%$ \\
\hline As a result of my study abroad experience... & $67 \%$ & $33 \%$ \\
\hline $\begin{array}{l}\text { I gained knowledge that can be applied in my professional } \\
\text { work }\end{array}$ & $68 \%$ & $12 \%$ \\
\hline I gained skills that can be applied in my professional work & $6 \begin{array}{l}\text { I gained a self-awareness that can be applied in my } \\
\text { professional work }\end{array}$ & 6 \\
\hline
\end{tabular}

"Survey responses "strongly agree" and "agree" have been combined under the heading "agree" and "strongly disagree" and "disagree" have been combined under the heading "disagree."

study abroad has significant long-lasting career impact and professional applicability. Results demonstrate that a majority of study abroad alumni in the sample gravitate toward a line of work with an international or multicultural dimension. Findings indicate that two program characteristics significantly contribute to professional outcomes in this arena. Alumni who lived in a homestay and alumni who were taught in a foreign language were more likely to work in a position with an international or multicultural dimension. There were, however, no findings that program type, program duration, or internship participation have significant bearings on professional work. Findings also suggest that knowledge, skills, and self-awareness gained by studying abroad are professionally applicable in the form of intercultural competences and personal growth. The data further indicates that many alumni are motivated by their experience in choosing a career path, with a majority of those influenced driven to work in the field of education, followed by banking/finance.

\section{Further Research}

Longitudinal outcomes assessment of study abroad is still in its early stages. Ideally, we design and implement a longitudinal, multi-case central design with a large sample of alumni surveyed at several points in their career. Further, it would be valuable to compare results from several diverse colleges and univer- 
sities. Investigating outcomes among participants at five, 15 , and 20 years out from their study abroad experience would help evaluate the professional value of study abroad over time. A supplementary collection of outcomes data on a control group would be useful in confirming causation of professional developments. Additional recommendations for further study include measuring the professional value of study abroad by surveying employers. The perspective of both human resource directors and hiring department directors may support or disclaim assertions made by alumni. A study of employers could examine major sets of criteria used in evaluating job candidates and provide a description of desirable competencies and personality traits found in study abroad alumni.

Findings from this study support the logic that study abroad has long-term professional benefits. Further investigation is needed to validate this claim, and ultimately the results need to be shared with appropriate parties to make beneficial use of the knowledge produced by the research.

\section{B i b li o g r a p h y}

109th U.S. Congress. (2005, November 10). Senate resolution 308. The Library of Congress. Retrieved June 23, 2008, from http://www.yearofstudyabroad. org/senate_resolution.asp

110th U.S. Congress. (2007, June 5). H. R. 1469. The Library of Congress. Retrieved June 23, 2008, from http://thomas.loc.gov/cgi-bin/query/ D?c110:4:./temp/ c110gedqpb

Akande, Y., \& Slawson, C. (2000, Summer). Exploring the long-term impact of study abroad: A case study of 50 years of study abroad alumni. International Educator, 9(3), 12-17.

Asia Society \& The Goldman Sachs Foundation. (2005). International knowledge crucial to student success and long-term economic health. PRIMEZONE Media Network. Retrieved June 23, 2008, from http://www.primezone. $\mathrm{com} /$ newsroom $/$ news.html?d=9094f4

Balkcum, A., Scheid, M., Vande Berg, M. J., \& Whalen, B. J. (2004, Fall). The Georgetown University consortium project: A report from the halfway mark. Frontiers: The Interdisciplinary Journal of Study Abroad, 10, 101-116.

Bolen, M. (2006). Basic student data and outcomes assessment in international education. The Forum on Education Abroad. Retrieved June 23, 2008, from http://www.forumea.org/research-position_papers.cfm

Bowen, W. G., \& Bok, D. (1998). The shape of the river: Long-term consequences of considering race in college and university admissions. Ewing, NJ: Princeton University Press. 
Brennan, M., Frost, R., Hagadorn, E., Martin, M., \& Natali, J. (2005). Education abroad on career development of community college students: Four case studies. In M. Tillman (Ed.), Impact of Education Abroad on Career Development: Four Community College Case Studies II (7-16). Stamford, CT: American Institute for Foreign Study Publications.

Dickinson College. (2005, March 24). The Mission of Dickinson College. In Strategic Plan II, FY 2006-2010. Retrieved June 23, 2008, from http:// www.dickinson.edu/plan/planII.htm

Dickinson College Office of Global Education. (2008). Dickinson programs. In Study Abroad Programs. Retrieved July 15, 2008, from http://www. dickinson.edu/global/programs/index.htm

Dickinson College Office of Institutional Research. (2008). Profile of graduating seniors. In Dickinson Facts. Retrieved June 23, 2008, from http://www. dickinson.edu/departments/insres/graduates.htm

Dwyer, M. M. (2004, Fall). More is better: The impact of study abroad program duration. Frontiers: The Interdisciplinary Journal of Study Abroad, 10, 151-163.

Dwyer, M. M. (2004). Charting the impact of studying abroad. International Educator, 13(1),14-20.

Dwyer, M. M., \& Norris, E. M. (2005, August). Testing assumptions: The impact of two study abroad program models. Frontiers: The Interdisciplinary Journal of Study Abroad, 11, 121-141.

Engle, L., Kenney, L., Kreutzer, K., Nolting, W., Ogden, A., \& Peterson, C. (2007). Defining terms for use in designing outcomes projects. In M. C. Bolen (Ed.), A Guide to Outcomes Assessment in Education Abroad (163-203). Carlisle, PA: The Forum on Education Abroad.

Evans, J., \& Meyer-Lee, E. (2007). Areas of study in outcomes assessment. In M. C. Bolen (Ed.), A Guide to Outcomes Assessment in Education Abroad (61-70). Carlisle, PA: The Forum on Education Abroad.

Fry, G. W., \& Paige, R. M. (2008, May 27). Proceedings from NAFSA conference 2008: Study Abroad for Global Engagement: A Preliminary Report on the SAGE Research Project. Washington, DC.

Hannigan, T. P. (2001, Fall). The effect of work abroad experiences on career development for U.S. undergraduates. Frontiers: The Interdisciplinary Journal of Study Abroad, 7, 1-23.

Hannigan, T. P. (2005). Collaboration between international education and career development professionals to improve the quality and impact of work abroad experiences. In M. Tillman (Ed.), Impact of Education Abroad 
on Career Development I (12-13). Stamford, CT: American Institute for Foreign Study Publications.

Hermans, J. (2007). High potentials: A CEO perspective. Journal of Studies in International Education, 11, 510-521.

Hunter, W. D. (2004 Spring). Got global competency. International Educator, $8(2), 6-12$.

Institute ofInternationalEducation.(2007,May).Current trendsin U.S. studyabroad $\&$ the impact of strategic diversity initiatives [White Paper]. Retrieved June 23, 2008, from http://www.iee.org/Content/NavigationMenu/Research_ and_Evaluation/Study_Abroad_White Papers/StudyAbroadCapacity.htm

Institute for International Education. (2007, November). U.S. students studying abroad. In Open Doors 2007: Report on International Educational Exchange. Retrieved May 12 2008, from http:opendoors.iienetwork.org/?p=113744 Jackson, J. (2005, August). Assessing intercultural learning through introspective accounts. Frontiers: The Interdisciplinary Journal of Study Abroad, 11, $165-203$.

Janson, K, \& Teichler, U. (2007). The Professional Value of Temporary Study in Another European Country: Employment and Work of Former ERASMUS Students. Journal of Studies in International Education, 11, 486-495.

Johnson, T. S., \& Kaufman, H. (2005, December 8). Send future US business leaders abroad. The Christian Science Monitor. Retrieved June 23, 2008, from http://csmonitor.com/2005/1208/p09s01-coop.html

Jongsma, A. (2007, October 21). US: American lawmakers promote study abroad. University World News. Retrieved July 7, 2008, from http://www. universityworldnews.com/article.php?story=20071018120925366

Kruze, L., Orahood, T., \& Pearson, D. E. (2004, Fall). The impact of study abroad on business students' career goals. Frontiers: The Interdisciplinary Journal of Study Abroad, 10, 117-149.

Matherly, C., \& Nolting, W. (2007, Fall). Where to next? Career pathways. Abroad View, 10(1), 38-39.

Norris, E. M., \& Norris, J. G. (2005, Spring). Study abroad: Stepping stone to a successful international career. NACE Journal, 65(3), 30-36.

Ostanina, G. A. (2005, May). The impact of study abroad on participants' personal and professional development. (Master's Capstone paper, School for International Training, 2005).

Paige, R. M., \& Stallman, E. M. (2007). Using instruments in education abroad outcomes assessment. In M. C. Bolen (Ed.), A Guide to Outcomes Assessment in Education Abroad (137-161). Carlisle, PA: The Forum on Education Abroad. 
Steinberg, M. (2007). The place of outcomes assessment in higher education today and the implications for education abroad. In M. C. Bolen (Ed.), $A$ Guide to Outcomes Assessment in Education Abroad (7-22). Carlisle, PA: The Forum on Education Abroad.

Stephenson, S. (2006). Globally responsible study abroad. International Educator, 15(6), 67-71.

U.S. Department of Labor, Bureau of Labor Statistics. (2007, October 19). Usual weekly earnings by educational attainment and sex. Retrieved July 7, 2008, from http://www.bls.gov/opub/ted/2007/oct/wk3/art05.htm

Vande Berg, M. (2006). A research-based approach to education abroad classification. The Forum on Education Abroad. Retrieved June 23, 2008, from http://www.forumea.org/research-position_papers.cfm

Weisman, N. (2001, Fall). Sustaining our study abroad tradition. Dickinsonian Magazine, 79(2), 3.

Wanasek, B. (2005). International service-learning: Impact on career choices. In M. Tillman (Ed.), Impact ofEducation Abroadon Career Development I(3334). Stamford, CT: American Institute for Foreign Study Publications.

Whalen, B. (2006). Study abroad outcomes assessment: Longitudinal studies. The Forum on Education Abroad. Retrieved June 23, 2008, from http:// www.forumea.org/research-position_papers.cfm

Whalen, B. (2001, November 28). Proceedings from the PACIE Conference 2008: Summary of Study Abroad Alumni Research. Carlisle, PA. 
